\title{
Flow Assurance in Subsea Pipeline Design - A Case Study of Ghana's Jubilee and TEN Fields*
}

\author{
${ }^{1}$ S. A. Marfo, ${ }^{2}$ P. Opoku Appau, ${ }^{1}$ J. Acquah and ${ }^{1}$ E. M. Amarfio \\ ${ }^{1}$ University of Mines and Technology, P.O. Box 237, Tarkwa, Ghana \\ ${ }^{2}$ Research Institute of Enhanced Oil Recovery, China University of Petroleum, Beijing, P. R. China
}

Marfo, S. A., Opoku Appau P., Acquah J., and Amarfio, E. M. (2019), "Flow Assurance in Subsea Pipeline Design - A Case Study of Ghana's Jubilee and TEN Fields", Ghana Mining Journal, Vol. 19, No. 1, pp. 72 - 85.

\begin{abstract}
The increasing exploration and production activities in the offshore Cape Three Point Blocks of Ghana have led to the discovery and development of gas condensate fields in addition to the oil fields which produce significant amount of condensate gas. These discoveries require pipelines to transport the fluids avoiding hydrates and wax formation. This paper focuses on subsea pipeline design using Pipesim software that addresses flow assurance problems associated with transporting condensate gas from the Jubilee and TEN Fields to the Atuabo Gas Processing Plant. It also considered an alternate design that eliminates the need for capacity increase of flowlines for the futuristic highest projected flow rates in 2030. The design comprises of two risers and two flowlines. Hydrate formation temperature was determined to be $72.5^{\circ} \mathrm{F}$ at a pressure of $3000 \mathrm{psig}$. The insulation thickness for flowlines 1 and 2 were determined to be $1.5 \mathrm{in}$. and 2 in. respectively. The pipe size for flowlines 1 and 2 were determined to be $12 \mathrm{in.}$ and $14 \mathrm{in.} \mathrm{respectively.} \mathrm{The} \mathrm{maximum} \mathrm{designed} \mathrm{flow} \mathrm{rate}$ was determined to be 150 MMSCFD. To meet the highest projected flow rate of 700 MMSCFD in the year 2030 at the processing plant, a $16 \mathrm{in}$. ID pipeline of $44 \mathrm{~km}$ length was placed parallel to the $12 \mathrm{in}$. ID flowline 1 . This parallel pipeline increased the designed flow rate by approximately 4.7 times (705 MMSCFD). The alternate design employs 18 in. and 20 in. ID pipes for flowlines 1 and 2 respectively.
\end{abstract}

Keywords: Condensate Gas, Flowline, Flow Assurance, Hydrate, Pipesim

\section{Introduction}

Pipeline in the oil and gas industry refers to a long line of connected segment of pipe with pumps, valves and other facilities needed for operating the system. Pipelines usually have a minimum diameter of $0.1 \mathrm{~m}$ and a minimum length of $1.6 \mathrm{~km}$ unless stated (Guha and Berrones, 2008). As the demand for energy continues to increase globally, exploration and production firms adapt to operational practices to meet the world's energy demand. This energy demand has led to the growing development of oil and gas activities offshores of many countries including that of Ghana, which requires safe and guaranteed means of transporting both crude and natural gas (condensate gas). Other means of transporting natural gas include use of tankers, conversion into Liquefied Natural Gas (LNG), Compressed Natural Gas (CNG), and gas to solid among others. However, transportation using pipelines are considered safe, economical, friendly to the environment and highly reliable (Singh and Nain, 2012). Although pipelines better guarantee continuous delivery and assures lower operating and maintenance cost, more challenges arise when transporting natural gas from offshore to onshore processing plant because temperature and pressure variations affect the physiochemical properties of the fluid transported (Ayala and Adewumi, 2003).

The subsea environment, which involves low temperatures as well as high pressures, high water cuts and longer transfer time provide conditions that are ideal for hydrates and wax formation and other solid deposits. These are the fundamental impairments to production of oil and gas through long distance subsea pipelines, especially at shutdown and restart situations (Akpabio, 2013). Hydrate related issues, severe riser slugging, wax formation, pressure and temperature losses, in natural gas pipelines have become a growing concern for the industry. In the quest to avert the above issues, Marfo et al. (2018) designed a subsea pipeline that transports natural gas from Gazelle Field in Côte d'Ivoire to a processing platform located $30 \mathrm{~km}$ to predict the conditions under which hydrate will form so as to be avoided. Their work anticipated hydrate to form at a temperature of $65^{\circ} \mathrm{F}$ for an arrival pressure of 800 psia thereby recommending flowline insulation thickness of $0.75 \mathrm{in}$. with specific pipe size of $10 \mathrm{in}$. to satisfy the arrival pressure condition. Similarly, this paper covers the design of a subsea pipeline system that addresses issues associated with transporting condensate gas from a satellite platform to a processing plant.

\subsection{Background of the Study Areas}

This research was conducted on the offshore waters of Ghana which covers Ghana's Jubilee Field, West Cape Three Points, and Tweneboa Enyerra Ntomme (TEN) Field. The pipeline covers a distance of about $59 \mathrm{~km}$ from the FPSO Kwame 
Nkrumah, with $44 \mathrm{~km}$ section of the pipeline positioned on the sea bed and the remaining $15 \mathrm{~km}$ on the water surface to the Onshore Receiving Facility (ORF) which is the Atuabo Gas Processing Plant. Brief description of the study areas are discussed:

\subsubsection{West Cape Three Point (WCTP) Discoveries}

The WCTP is located at the Tano basin in the Gulf of Guinea, covering an area of 457294776 gross $\mathrm{m}^{2}$ with water depth ranging from $50-1798 \mathrm{~m}$. The discoveries by Kosmos Energy made at the block include; The Jubilee Oil Field, 2007, the Mahogany Oil Field, 2008, the Teak Oil and Gas condensate Fields, 2011 and the Akasa Oil Field, 2011 (McLaughlin, 2012).

\subsubsection{Jubilee Field}

Jubilee oil Field is located in deep-water of about $1100-1700 \mathrm{~m}$ depth and an approximate distance of $60 \mathrm{~km}$ from the nearest coast in the Western Region of Ghana. The field covers an area of 109 265220 gross $\mathrm{m}^{2}$ and a total gross resources of 600 MMbbl with upside. The production from the field averaged approximately 102000 bopd. The field underlies portions of the West Cape Three Point and Deep-water Tano License Blocks. The field start-up occurred on November 28, 2010 and production has continued to ramp up as additional phase one wells has been brought online. The phase 1 development programme consists of 17 wells, 9 producers, 6 water injectors, and 2 gas injectors which target the lower and upper Mahogany reservoirs (McLaughlin, 2012).

\subsubsection{TEN Field}

The Jubilee partners discovered a significant gas condensate accumulation at the Tweneboa Field in 2009, followed by the Enyenra oil Field in 2010. Further drilling success resulted in the discovery of oil at the Ntomme Field, and oil and gas condensate at Wawa in 2012. Initial development of the discoveries on the Deep-water Tano block focused on the Enyenra and Ntomme oil fields, utilising a Floating Production, Storage and Offloading (FPSO) vessel. Production from Tweneboa, Enyenra, and Ntomme (TEN) began in August 2016 (Anon, 2014).

\subsubsection{The Floating, Production, Storage and} Offloading Vessel (FPSO)

The FPSO Kwame Nkrumah which is named after the first president of Ghana was installed in November 2010, at a water depth of $1100 \mathrm{~m}$. It is designed to operate for 20 years. The facility processes 120000 bpod and $160 \mathrm{Mscfd}$ of gas, and has a storage capacity of 1.6 million bbl of oil (Anon, 2013; Anon, 2014). Table 1 shows the production ranges for the operating parameters and specification of FPSO Kwame Nkrumah.

\subsubsection{The Atuabo Gas Processing Plant (AGPP)}

The Atuabo gas processing plant or the Ghana Gas Company located at Atuabo in Western Region of Ghana is designed to receive natural gas from the fields in Ghana. The plant has a capacity of 140 MMSCFD of natural gas. It is designed to process a minimum of $140000000 \mathrm{~kg}$ of Liquefied Petroleum Gas (LPG) for domestic use and deliver about $46000000 \mathrm{~kg}$ of condensate and about 150 $000000 \mathrm{~kg}$ of isopentane (Anon, 2014). The associated gas from all the Cape Three Points Fields have to be channeled to the gas plant for further processing.

The study area is shown in Fig 1.

Table 1 Jubilee FPSO Function Specification

\begin{tabular}{|l|l|}
\hline Parameters & Jubilee Production \\
\hline Total fluid rate & $160000 \mathrm{BLPD}$ \\
\hline Oil production rate & $120000 \mathrm{BOPD}$ \\
\hline Produced water rate & $80000 \mathrm{BWPD}$ \\
\hline Produced gas rate & $160 \mathrm{MMSCFD}$ \\
\hline $\begin{array}{l}\text { Topsides arrival } \\
\text { pressure }\end{array}$ & $\begin{array}{l}34.5-55.2 \mathrm{BAR}(500- \\
800 \mathrm{psig})\end{array}$ \\
\hline Arrival temperature & $49-60^{\circ} \mathrm{C}\left(120-140^{\circ} \mathrm{F}\right)$ \\
\hline $\begin{array}{l}\text { Flowline shut-in } \\
\text { pressure }\end{array}$ & $414 \mathrm{BAR}(6000 \mathrm{psig})$ \\
\hline $\begin{array}{l}\text { Water injection } \\
\text { pressure }\end{array}$ & $345 \mathrm{BAR}(500 \mathrm{psig})$ \\
\hline Water injection rate & $232000 \mathrm{BPD}$ minimum \\
\hline $\begin{array}{l}\text { Gas injection } \\
\text { pressure }\end{array}$ & $5500 \mathrm{psig}$ \\
\hline Gas injection rate & $160 \mathrm{MMSCFD}$ \\
\hline Gas export rate & $707 \mathrm{BAR}(3000 \mathrm{psig})$ \\
\hline Gas export rate & $160 \mathrm{MMSCFD}$ \\
\hline
\end{tabular}

(Source: Weinbel and Araujo, 2012)

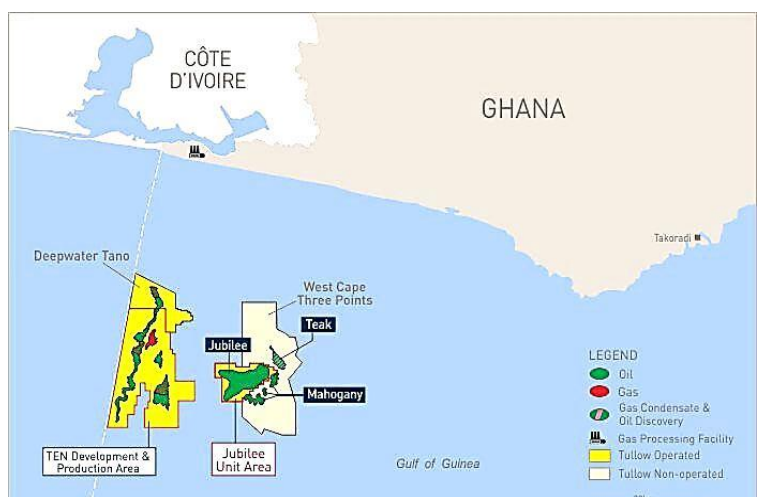

Fig 1 West Cape Three Points, Jubilee Field, TEN Field and Atuabo Gas Plant (Source: Anon, 2014) 


\subsection{Overview of Flow Assurance}

Flow assurance refers to ensuring successful and economical flow of hydrocarbon stream from a reservoir to the point of sale. Flow assurance includes thermal investigation of pipelines, ensuring temperature is above hydrate's formation temperature (Anand and Anirbid, 2015). Blocked oil and gas pipelines, is one of the industry's challenges, resulting in loss of revenue. It has therefore been important to find solutions for oil and gas pipelines to avoid such incidents (Sum, 2013). Flow assurance is considered a critical task during subsea transportation of natural gas because of the anticipated high pressure and low temperature (Obanijesu et al., 2010). The following are some of the challenges that results in flow assurance problems in subsea transportation of condensate:

\subsubsection{Hydrate Formation}

There are three different forms of hydrate structures. These are; the cubic structure I (s1), cubic structure II (sII) and hexagonal structure $\mathrm{H}$ (sH). Gas such as methane $\left(\mathrm{CH}_{4}\right)$ and carbon dioxide $\left(\mathrm{CO}_{2}\right)$ mostly form s1 hydrates while natural gas form sII hydrates (Mokhatab et al., 2006; Ripmeester et al., 1987). Hydrates are solid crystalline compounds whose structure is made of a hydrogen bonded water molecules and a gas molecules (Gabitto and Tsouris, 2010). Gas hydrate causes many flow assurance problems which include; reduction of the pipe internal diameter, flow restriction, increased pumping pressure, reduced throughput and increased surface roughness (Broni-Bediako et al., 2017). There are a number of factors, which contribute to gas hydrate formation. The major ones include; free water condensing out of a gas, hydrate formers such as methane, ethane, propane, isobutane, nitrogen, hydrogen sulphide, and carbon dioxide; low temperature and high pressure conditions (Ameripour, 2005). The determination of hydrate formation conditions in a pipeline is one of the major operations the oil and gas industry is concerned with, as subsea conditions favour hydrate formation. Due to the conditions under which gas hydrate forms, there is no unique method of preventing its formation. Gas hydrate formation can be prevented in the following ways; by preventing free water in the gas, either dehydrating the gas or increasing the temperature to vaporise more water; introducing chemical inhibitors such as methanol, ethanol and glycol into the pipeline system (Covington and Collie, 1997).

\subsubsection{Wax Deposition and Gelation}

Wax formation and deposition is one of the major problems associated with pipeline transportation of crude oil and condensates. Wax deposition can foul the internal surface, which results in increasing pressure drop. Wax deposition depends more on a flow temperature since it only deposits on the walls of a pipe when the wall's temperature is below the cloud point and colder than the bulk fluid (Akpabio, 2013). Waxes that precipitate out of the flow stream consist of normal paraffin and naphthenes (Theyab and Diaz, 2016). According to Karen and Rønningsen (2003), wax precipitation within pipelines at and below the cloud point of the fluid can cause gelling inhibiting flow. Factors such as fluid viscosity, paraffin content, flow rate, gas-oil ratio, and the overall heat transfer coefficient affect the deposition rate of wax (Golczynski and Kempton, 2006).

\subsubsection{Pipeline Slugging}

Slugs can cause damage to facilities, separator flooding, increased corrosion, starving compressors and high backpressure. There are different forms of slugs such as hydrodynamic slugs, terrain induced slugs, turn up slugs, and pigging slugs. Terrain induced slugging normally occurs when liquid is trapped in the pipeline at low spots. Riser slugging is a type of terrain induced slugging which occurs at the riser base and normally depend on the flow rate (Mokhatab et al., 2006).

\subsubsection{Temperature Losses Control Mechanisms}

The transportation of condensate gas through a pipeline over a long distance requires a set temperature to be maintained in order to avoid hydrate formation, wax formation and deposition and wax gelation. Due to this regard, temperature losses across the distance of the pipeline are of paramount concern (Nikhar, 2006). According to Okologume and Appah (2015), thermal insulation of subsea pipeline is of essential need in the design and operation of subsea pipelines since it helps preserve heat and maintains the operating temperature beyond the hydrate region. Direct Electrical Heating (DEH) is a flow assurance technology developed to safeguard the well stream through the pipeline to the platform. The pipe is heated by running alternating current through the steel in the pipe (Nexans, 2015). DEH has really proved to be cost effective, highly reliable, and flexible. Industry partners have used DEH at selected fields since 2000, and the method has proved very good under various operating conditions. So far, the method is used up to $1 \mathrm{~km}$ water depth and approximately $45 \mathrm{~km}$ pipeline length (Nysveen et al., 2005). DEH system is, 
effective and efficient over short distances and it is environmentally friendly than chemical inhibition. Over longer distances, both chemical inhibition and DEH may not be economically viable to be utilised (Akpabio, 2013).

\section{Resources and Methods Used}

In order to design a suitable pipeline for transporting condensate gas for the Jubilee and TEN Fields, the following methods were employed in this work; considering the minimum required parameters in the design of subsea pipeline but not limited to temperature of flowlines; pipeline pressure losses; gas composition and properties; desired mass flow rate; elevation at exporting terminal (FPSO); distance between exporting terminal and the receiving facility; Weymouth equation and Pipesim.

\subsection{Pipeline Design Parameters}

Data on gas composition, properties and gas entry pressure were taken from the 2013 Jubilee Field reports and literature. Other data such as annual water temperature, data on the Atuabo Gas Processing Plant (AGPP) were obtained from Tullow Ghana Limited's website. However, data on TEN gas composition were taken from 2014 Environmental Impact Assessment report of the TEN Project. Table 2 presents secondary data taken from the relevant study areas.

\subsubsection{Temperature of Flowlines}

To determine the ambient temperature of the pipeline, flowline 1 assumed the temperature of Ghana's seawater. Temperature profile of the seawater (Fig 2) along the coast of Ghana was used to determine the temperature at various depths of interest for flowline 1 (Anon, 2009). Flowline 2 assumes an average onshore ambient temperature of $80.6{ }^{\circ} \mathrm{F}$.

\subsubsection{Pipeline Pressure Losses}

This includes the inlet pressure at the FPSO exporting terminal, the length of the pipeline, the flow regime, the operating flow rate, the roughness of the pipes, the outlet pressure of the onshore receiving terminal at the gas processing plant (Table 2). The average inlet pressure of the gas exported from the FPSO used for this work is 3000 psig. The pressure drops to 2400 psig after a distance of $44 \mathrm{~km}$ and then, $700 \mathrm{psig}$ at the Onshore Receiving Facility (ORF) (Anon, 2013).

\subsubsection{Gas Composition and Properties}

The average gas compositional values were used for this work. The data on the gas composition and properties were taken from different sources including Tullow Oil Ghana Limited. Table 3 provides a comprehensive data on gas composition from the Jubilee and TEN Fields while Table 4 giving a yearly projected flow rate to Atuabo Gas Processing Plant (AGPP) (Anon, 2014).

\subsection{The Weymouth Equations}

The Weymouth equation for non-horizontal flow was used for this work. The reason being that, the fluid assumes a high-Reynolds-number flow where the Moody friction factor is merely a function of relative roughness. It is assumed that the elevation $\Delta \mathrm{z}$ is uniformly sloped; flowlines temperature remains constant at designated points and also the flow in the pipe is steady state flow (Weymouth, 1912; Moody, 1944).

2.2.1 Weymouth equation for flow rate:

$$
\begin{gathered}
q_{h}=\frac{3.23 \mathrm{~T}_{b}}{P_{b}} \sqrt{\frac{\left(P_{1}{ }^{2}-e^{S} P_{2}^{2}\right) D^{5}}{f \gamma_{g} \bar{T} \bar{z} L_{e}}} \\
L e=\frac{\left(e^{2}-1\right) L}{S} \\
S=\frac{0.0375 \gamma_{g} \Delta z}{\bar{T} \bar{z}} \\
N_{\operatorname{Re}}=\frac{D u \rho}{\mu}
\end{gathered}
$$

Moody friction factor, $f$

$$
\frac{1}{\sqrt{f}}=1.14-2 \log \left(e_{D}+\frac{21.25}{N_{\operatorname{Re}}}\right)
$$

where;

$\begin{array}{lll}\mathrm{P}_{1} & = & \text { upstream pressure, psi } \\ \mathrm{P}_{2} & = & \text { downstream pressure, } \mathrm{psi} \\ \mathrm{T} & = & \text { average temperature, }{ }^{\circ} \mathrm{R} \\ \mathrm{Z} & = & (\mathrm{P} 1-\mathrm{P} 2) / 2 \\ \mathrm{~T}_{\mathrm{b}}, \mathrm{P}_{\mathrm{b}} & = & \text { operating temperature and } \\ & & \text { pressure } \\ \mathrm{q}_{\mathrm{h}} & = & \text { flow rate measured at the base } \\ & & \text { conditions, MCFD. } \\ \mathrm{N}_{\mathrm{Re}} & = & \text { Reynolds Number } \\ f & = & \text { friction factor } \\ \hat{\mathrm{Z}} & = & \text { gas deviation factor at } \mathrm{T} \text { and } \mathrm{P} \\ \mathrm{u} & = & \text { fluid velocity, } \mathrm{ft} / \mathrm{sec} \\ \rho & = & \text { fluid density, } \mathrm{lbm} / \mathrm{ft}^{3} \\ \mathrm{D} & = & \text { pipe diameter, in } \\ \gamma_{\mathrm{g}} & = & \text { gas gravity }\end{array}$




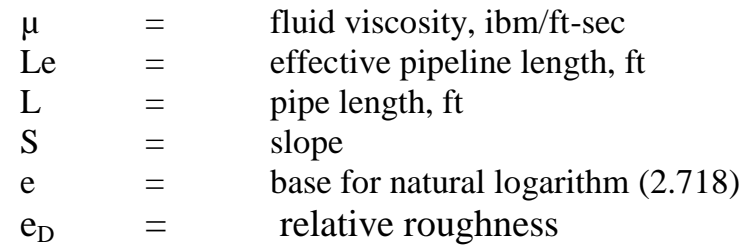

2.2.2 Weymouth equation for parallel capacity increase

$$
\frac{q_{t}}{q_{1}}=\frac{\sqrt{D_{1}^{16 / 3}}+\sqrt{D_{2}^{16 / 3}}+\sqrt{D_{3}^{16 / 3}}}{\sqrt{D_{1}^{16 / 3}}}
$$

where;

$\mathrm{q}_{\mathrm{t}}=\quad$ total flow rate MMSCFD

$\mathrm{q}_{1}=\quad$ initial flow rate MMSCFD

$\mathrm{D}_{1}=$ internal diameter of flowline 1

$\mathrm{D}_{2}=$ internal diameter of parallel connected

flowline

$\mathrm{D}_{3}=$ internal diameter of flowline 2

\subsubsection{Slugging calculation}

$$
\text { Slug length }=\frac{\text { Riser height }}{P I-S S \text { number }}
$$

where;

PI - SS $=$ Slug number PI - SS number less than 1 means severe slugging

PI - SS number greater than 1 means no slugging

\subsection{Pipesim Computation}

Pipesim software was used to determine the hydrate phase envelope, pipe size, insulation thickness and the heating temperature of the DEH system. The software requires the input of the pure gas components and the addition of the characterised heavier hydrocarbon components, to generate the phase envelope of the fluid composition. The size of the pipeline was determined by computing FPSO inlet pressure and temperature as a source conditions, the design flow rate, the roughness, the overall heat transfer coefficient and ambient temperature, the ground conductivity and a range of pipe diameters.

Table 2 Relevant Field Data of the Study Areas

\begin{tabular}{|l|c|c|c|}
\hline Parameters & Value & Parameters & Value \\
\hline Water Depth $(\mathrm{m})$ & 1100 & ORF Inlet Pressure $(\mathrm{psig})$ & 1015 \\
\hline Subsea Temperature $\left({ }^{\circ} \mathrm{F}\right)$ & 41 & ORF Inlet Temperature $\left({ }^{\circ} \mathrm{F}\right)$ & 74 \\
\hline FPSO Inlet Pressure $(\mathrm{psig})$ & 3000 & Gas Density (API) & 37 \\
\hline FPSO Inlet Temperature $\left({ }^{\circ} \mathrm{F}\right)$ & 160 & Gas Viscosity $(\mathrm{cP})$ & 0.16 \\
\hline Current Gas Production $(\mathrm{MMSCFD})$ & 160 & ORF current capacity (MMSCFD) & 300 \\
\hline Gas Gravity & 0.64 & & \\
\hline
\end{tabular}

(Source: Anon, 2013)

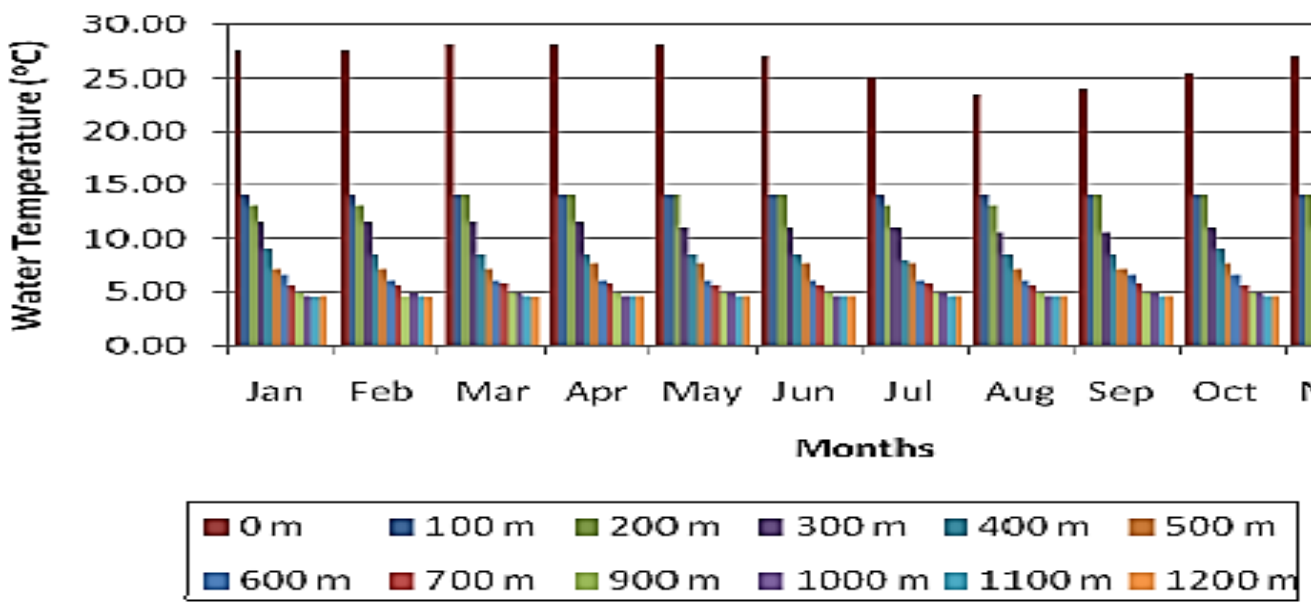

Fig 2 Profile of Water Temperature Offshore Ghana (Source: Anon, 2009) 
Table 3 Data on Gas Composition

\begin{tabular}{|l|c|c|c|c|c|}
\hline COMPONENT & JUBILEE & JUBILEE & TEN & TEN & AVERAGE \\
\hline $\mathrm{C} 1$ & 77.65 & 79.197 & 76.392 & 76.645 & 77.440 \\
\hline $\mathrm{C} 2$ & 6.344 & 5.265 & 6.943 & 5.867 & 6.105 \\
\hline $\mathrm{C} 3$ & 5.387 & 2.583 & 4.241 & 4.125 & 4.084 \\
\hline $\mathrm{C} 4$ & 0.677 & 0.241 & 0.994 & 0.705 & 0.594 \\
\hline $\mathrm{IC} 4$ & 0.167 & 1.665 & 2.198 & 0.283 & 1.257 \\
\hline $\mathrm{C} 5$ & 0.325 & 0.378 & 0.453 & 0.315 & 0.418 \\
\hline $\mathrm{IC} 5$ & 0.409 & 0.301 & 1.005 & 0.177 & 0.384 \\
\hline $\mathrm{C} 6$ & 0.005 & 0.023 & 0.278 & 0.357 & 0.115 \\
\hline $\mathrm{C} 7+$ & 7.394 & 7.534 & 7.003 & 9.822 & 7.938 \\
\hline $\mathrm{N}_{2}$ & 0.385 & 0.0995 & 0.466 & 0.336 & 0.241 \\
\hline $\mathrm{CO}_{2}$ & 1.424 & 1.415 & 1.442 & 1.314 & 1.424 \\
\hline $\mathrm{H}_{2} \mathrm{~S}$ & 0.003 & 0.0074 & 0.00004 & 0.013 & 0.0004 \\
\hline
\end{tabular}

Table 4 Yearly Projected Flow Rate to AGPP

\begin{tabular}{|l|l|}
\hline YEAR & FLOW RATE \\
\hline 2014 & 120 MMSCFD \\
\hline 2015 & 150 MMSCFD \\
\hline 2016 & 300 MMSCFD \\
\hline 2017 & 300 MMSCFD \\
\hline 2018 & 450 MMSCFD \\
\hline 2019 & 450 MMSCFD \\
\hline 2020 & 560 MMSCFD \\
\hline 2025 & 640 MMSCFD \\
\hline 2030 & 700 MMSCFD \\
\hline
\end{tabular}

\section{Results and Discussion}

To address the major flow assurance problems while minimising cost and satisfying the field operating conditions, two pipeline designs were considered. For the purpose of simplicity, the two final designs are presented in a tabular form. Table 5 outlines the initial design specifications while Table 6 outlines the specifications of the alternate design. The two risers have the same specifications in both designs. Fig 3 shows orientation of the full design, indicating Source 1 (FPSO) and S1 (ORF, Atuabo Gas Processing Plant). The designs limitation and the necessary solution for efficient delivery are also presented.

The hydrate formation temperature and pressure were determined from the hydrate phase envelope generated by the addition of water content to the inputted fluid composition. Fig 4 shows the hydrate phase envelope generated. From the hydrate phase envelope, the temperature below which hydrate will form is $72.5^{\circ} \mathrm{F}$.

\subsection{Selection of Optimal Pipeline Sizes}

A range of pipe sizes were simulated to determine the minimum pipe size that meets the pressure requirements at the designated points which will maintain a higher flow rate. The pipe size selected for flowline 1 must satisfy a boundary conditions of $44 \mathrm{~km}$ length and a pressure above 2800 psig whilst the pipe size for flowline 2 must satisfy a boundary conditions of $15 \mathrm{~km}$ length and a pressure above 1010 psig (Fig 5 and Fig 6 respectively). The minimum pipe size that met the boundary conditions for flowline 1 was 12 in. while that of flowline 2 was $14 \mathrm{in}$. This is because the 10 in. pipe size for flowline 1 did not meet output pressure required to flow the gas through riser 2 and flowline 2 to the ORF. Therefore, a 12 in. pipe size was selected instead. Similarly, a 14 in. was selected for flowline 2 instead of $12 \mathrm{in}$. because the 12 in. pipe did not meet the inlet pressure of the ORF.

\subsection{Optimal Insulation for Pipelines}

The optimal insulation thickness for flowline 1 was determined to be $1.5 \mathrm{in}$. while that of flowline 2 was 2 in. The ambient temperature of flowline 1 was raised from $41{ }^{\circ} \mathrm{F}$ to $80{ }^{\circ} \mathrm{F}$ using Direct Electrical Heating (DEH). Fig 7 shows a range of 
flow rate for flowline 1 when an insulation thickness of $1.5 \mathrm{in}$. was used and Fig 8 shows a range of flow rates when an insulation thickness of $2 \mathrm{in}$. was used for flowline 2. The insulation of the pipe has a direct effect on the flow rate. The insulation improves the flow rate of the gas. A better insulation gives a higher flow rate. The insulation material used in the design has a thermal conductivity of $0.15 \mathrm{Btu} / \mathrm{hr} / \mathrm{ft} /{ }^{\circ} \mathrm{F}$. The insulation thickness for flowline 1 was 1.5 in. whilst that for flowline 2 was $2 \mathrm{in}$. In order to operate above the hydrate formation temperature, a Direct Electrical Seating (DEH) system was, incorporated into the design to raise the temperature of flowline 1 above the hydrate formation temperature due to the low subsea temperature. Flowline 1 was insulated and then heated using the DEH to raise the ambient subsea temperature of $41{ }^{\circ} \mathrm{F}$ to $80{ }^{\circ} \mathrm{F}$.

\subsection{Addressing Riser Slugging Challenges}

The initial design has a minimum PI-SS number (slug number) of 4.95 (Table 8) and that of the alternate design was 1.6 (Table 9). Both designs have their PI-SS number greater than 1 indicating no liquid slugging at the riser base will occur.

A PI-SS number or slugging value greater than 1 means an absence of liquid slugging at the riser base whilst a PI-SS number less than 1 means that there is a possibility that liquid slugging will occur. Severe riser slugging can be determined from the PI-SS number using equation 7. A PI-SS or slug number of 4.95 (Table 8) was obtained for the initial design and a 1.6 (Table 9) for the alternate design. Both designs have their PI-SS number greater than 1 indicating no liquid slugging at the riser base. Since the PI-SS values obtained indicate no liquid slugging at the riser base, it also means that severe riser slugging will not occur.

\subsection{Addressing Flow Assurance Challenges}

The hydrate formation temperature obtained from the hydrate phase envelope at a defined pressure of 2555 psia is approximately $73{ }^{\circ} \mathrm{F}$ (Fig 4). Wax formation was not detected at the minimum subsea temperature of $41{ }^{\circ} \mathrm{F}$ as shown in Fig 4. The absence of wax precipitation and deposition in the flowlines was due to the absence of heavier hydrocarbon components and the increased surrounding temperature by the direct electrical heating system.

The maximum flow rate of the design is 150 MMSCFD which does not meet the projected flow rates from the year 2016. The highest flow rate from the fields to the processing plant is projected to be 700 MMSCFD in 2030 (Table 4). This therefore requires a capacity increase in the flowlines. The capacity increase in flowline 1, was computed to obtain the smallest pipe size which when run parallel to the 12 in. pipe will increase the design flow rate of 150 MMSCFD to 700 MMSCFD or more. Table 7 shows the output of the capacity increase in Flowline 1.

Table 5 Specification of the Design

\begin{tabular}{|l|c|c|c|c|}
\hline PARAMETER & FLOWLINE 1 & FOWLINE 2 & RISER 1 & RISER 2 \\
\hline Pipe length (m) & 44000 & 15000 & 1100 & 1100 \\
\hline Pipe size (in) & 12 & 14 & 10 & 10 \\
\hline Pipe thickness (in) & 1.0 & 1.0 & 0.5 & 0.5 \\
\hline Ambient temperature $\left({ }^{\circ} \mathrm{F}\right)$ & 41.0 & 80.6 & 68.0 & 68.0 \\
\hline Thermal insulation thickness (in) & 1.5 & 2.0 & 0.0 & 0.0 \\
\hline Temperature by DEH $\left({ }^{\circ} \mathrm{F}\right)$ & 40.0 & 0.0 & 0.0 & 0.0 \\
\hline Roughness & 0.001 & 0.001 & 0.001 & 0.001 \\
\hline Pipe conductivity $\left(\mathrm{Btu} / \mathrm{hr} / \mathrm{ft} /{ }^{\circ} \mathrm{F}\right)$ & 50 & 50 & 35 & 35 \\
\hline Flow rate $(\mathrm{MMSCFD})$ & & & & \\
\hline
\end{tabular}




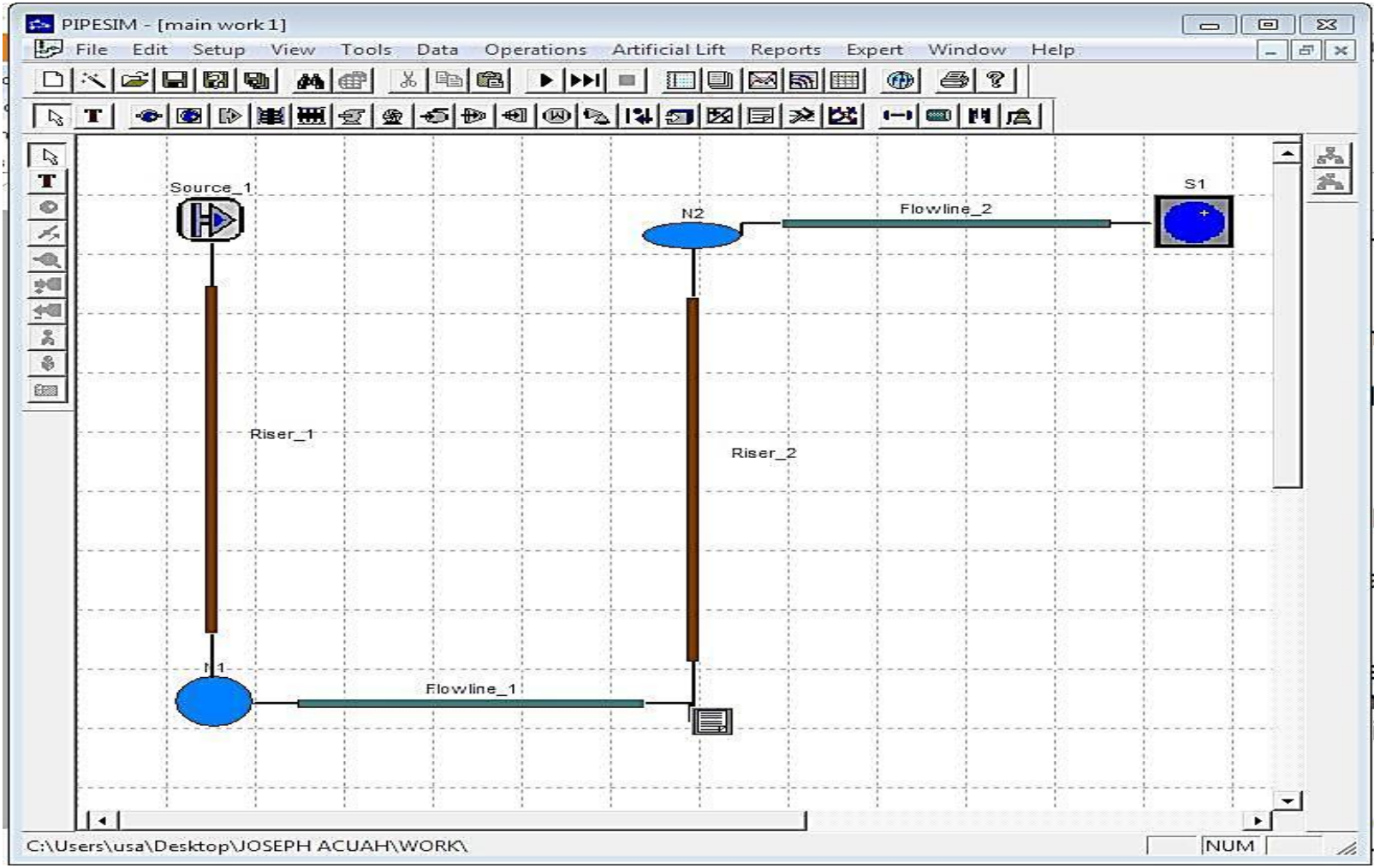

Fig 3 Pipesim Interface Showing the Full Design Orientation

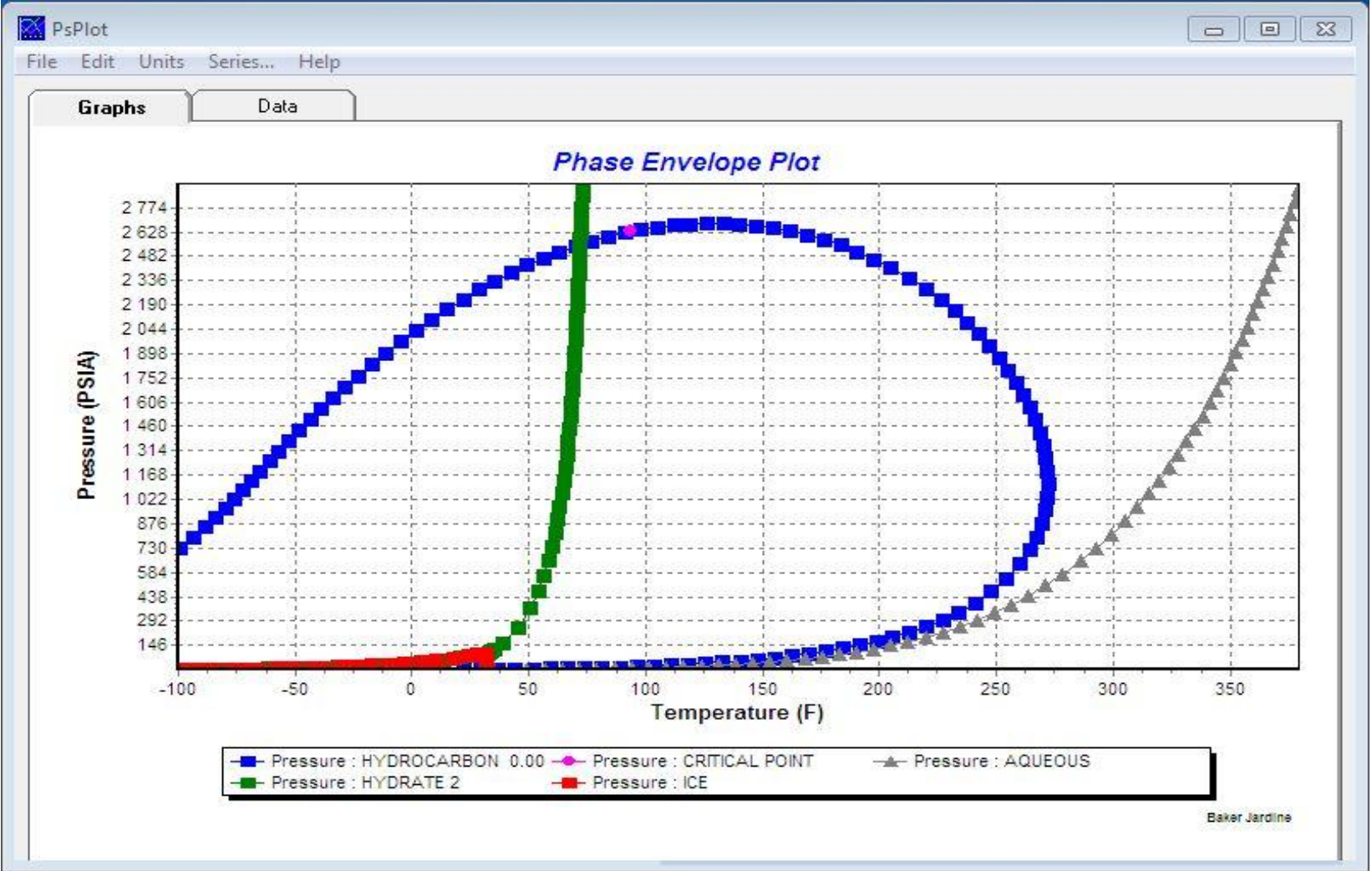

Fig 4 Hydrate Phase Envelope Showing Hydrate Formation Temperature 


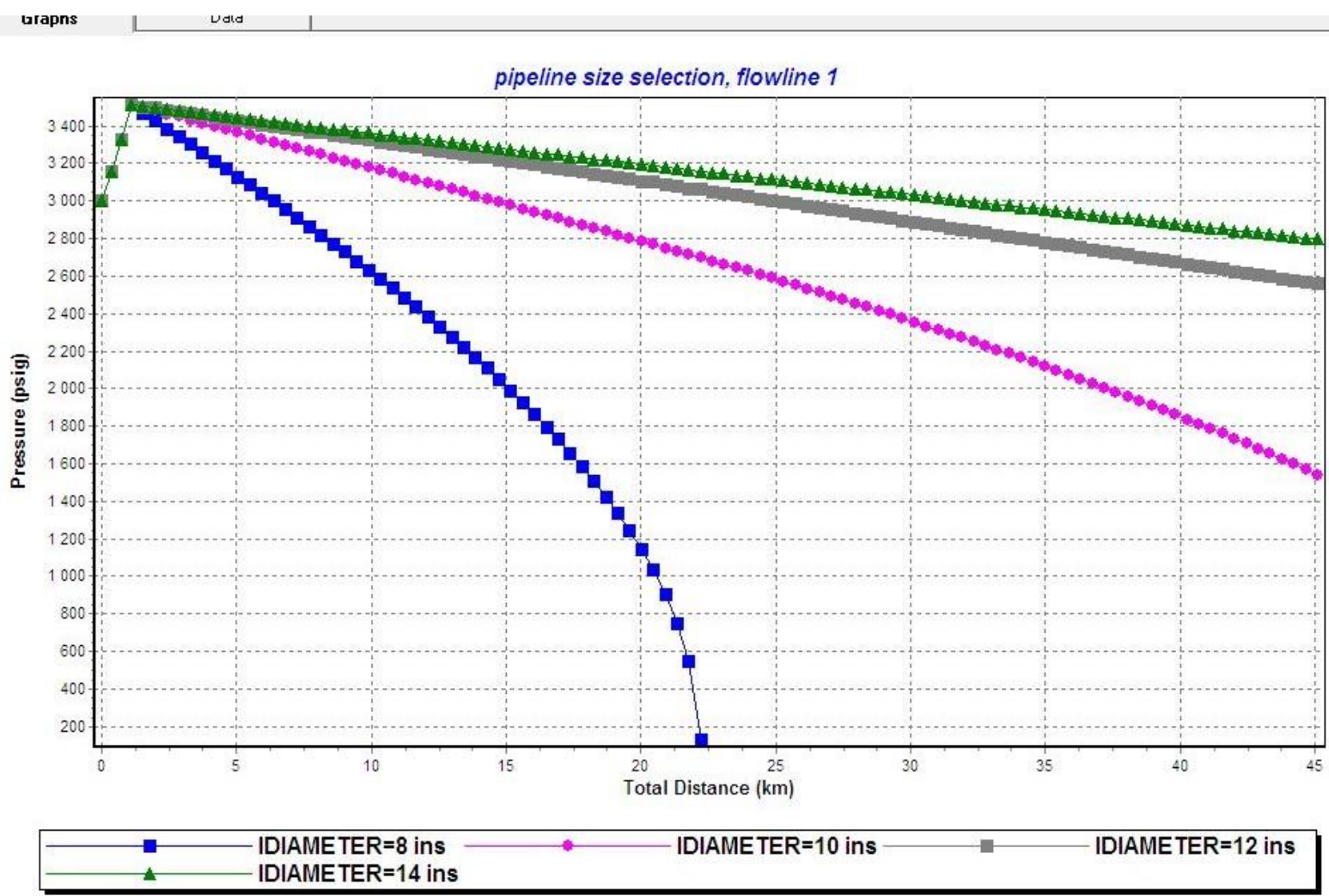

Fig 5 Pressure - Distance Plot Showing Pipe Sizes for Flowline 1

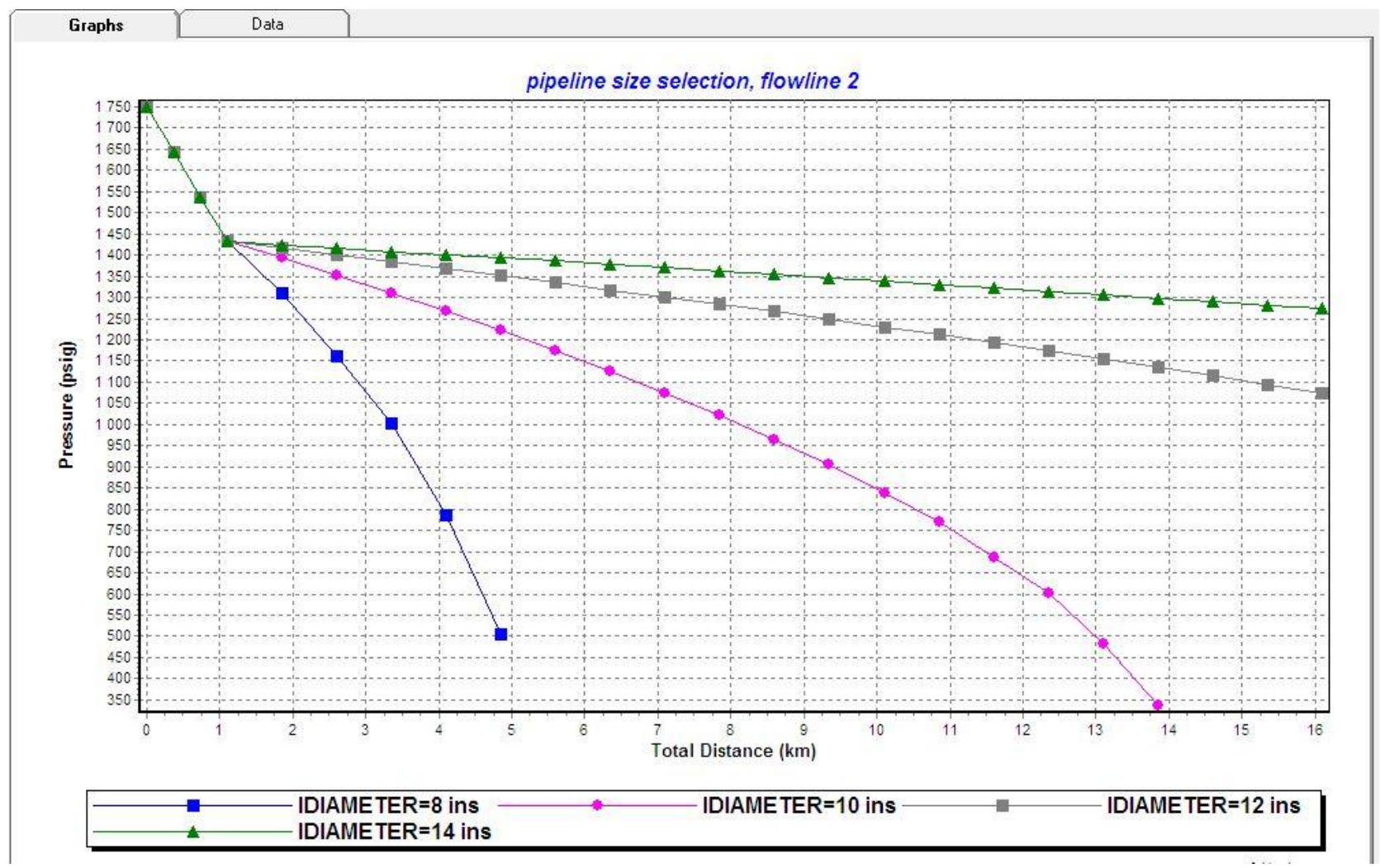

Fig 6 Pressure - Distance Plot Showing Pipe Sizes for Flowline 2 
1.5 in thermal insulation flowline 1

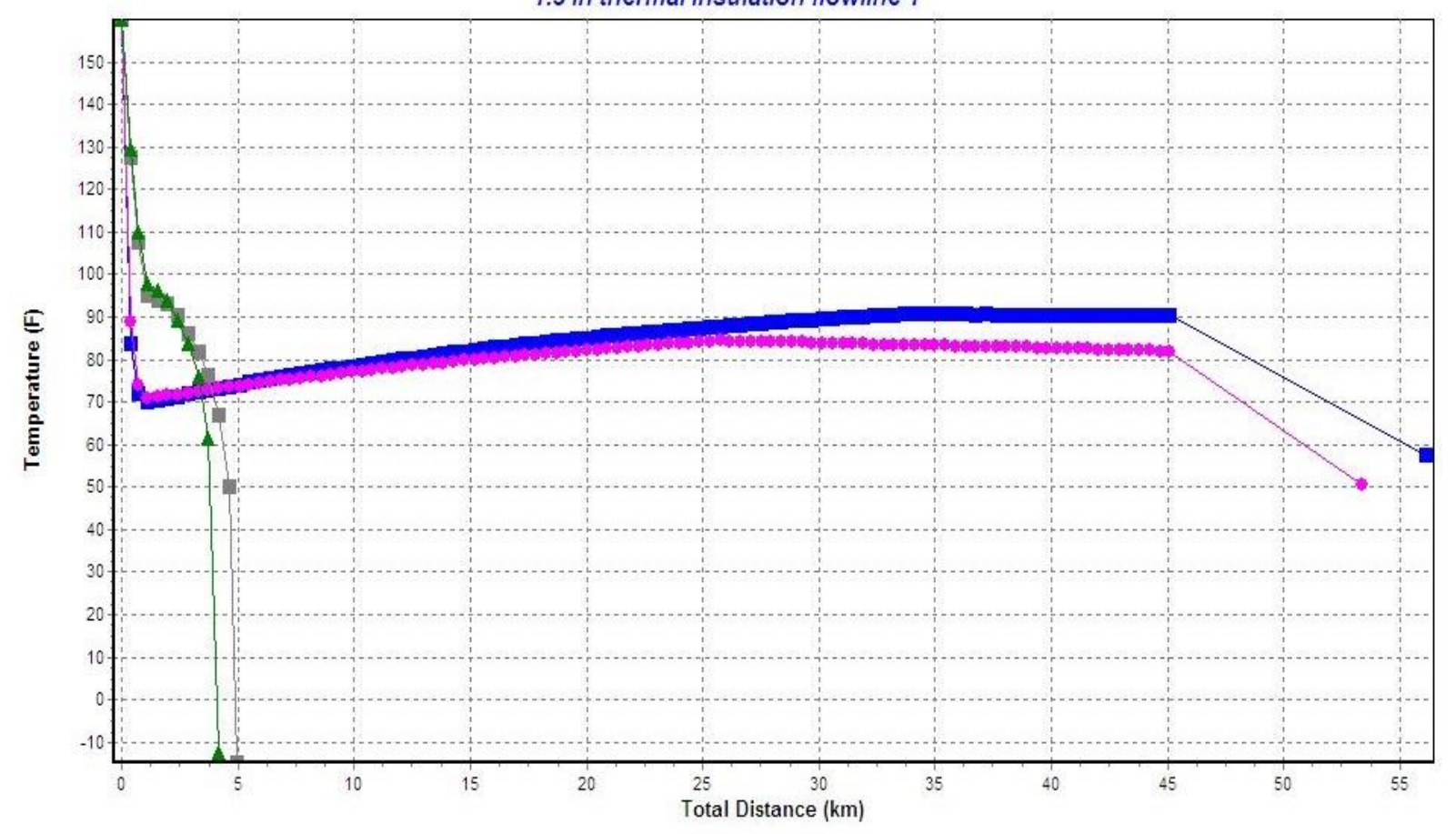

$\begin{array}{r}\longrightarrow \text { GAS }=120 \mathrm{mmscfd} \\ \mathrm{GAS}=700 \mathrm{mmscfd}\end{array} \mathrm{GAS}=150 \mathrm{mmscfd} \longrightarrow \mathrm{GAS}=640 \mathrm{mmscfd}$

Fig 7 Temperature - Distance Plot Showing the Flow Rates for Flowline 1

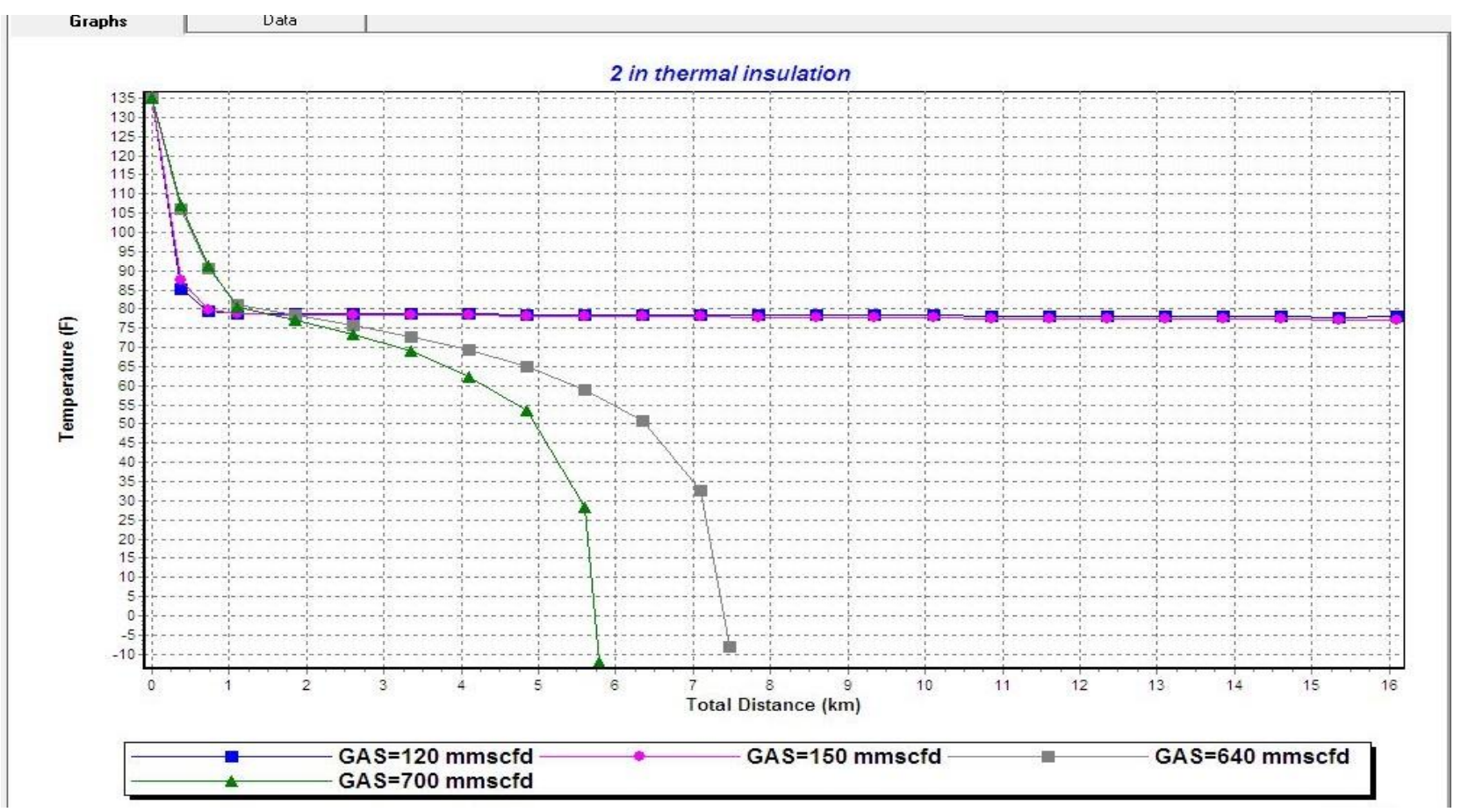

Fig 8 Temperature - Distance Showing the Flow Rates for Flowline 2 
Table 6 Specification for an Alternative Design

\begin{tabular}{|c|c|c|c|c|}
\hline PARAMETER & FLOWLINE 1 & FOWLINE 2 & RISER 1 & RISER 2 \\
\hline Pipe length (m) & 44000 & 15000 & 1100 & 1100 \\
\hline Pipe size (in) & 18 & 20 & 10 & 10 \\
\hline Pipe thickness (in) & 1 & 1 & 0.5 & 0.5 \\
\hline Ambient temperature $\left({ }^{\circ} \mathrm{F}\right)$ & 41 & 80.6 & 68 & 68 \\
\hline Thermal insulation thickness (in) & 1.5 & 2 & - & - \\
\hline Temperature by DEH $\left({ }^{\circ} \mathrm{F}\right)$ & 40 & - & - & - \\
\hline Roughness & 0.001 & 0.001 & 0.001 & 0.001 \\
\hline Pipe conductivity $\left(\mathrm{Btu} / \mathrm{hr} / \mathrm{ft} /{ }^{\circ} \mathrm{F}\right)$ & 50 & 50 & 35 & 35 \\
\hline
\end{tabular}

Table 7 Capacity Increase of Flowline 1

\begin{tabular}{|c|c|c|c|c|c|}
\hline \multirow{2}{*}{$\begin{array}{c}\text { PIPE ID } \\
(\text { IN) }\end{array}$} & \multicolumn{2}{|c|}{ PARALLEL PIPE CAPACITY INCREASE } & \multicolumn{2}{c|}{$\begin{array}{c}\text { YEARLY PROJECTED FLOW } \\
\text { RATE }\end{array}$} \\
\cline { 2 - 6 } & $\begin{array}{c}\text { FLOWLINE } \\
\mathbf{1}\end{array}$ & $\begin{array}{c}\text { FLOWLINE } \\
\mathbf{2} \\
(\mathbf{M})\end{array}$ & $\begin{array}{c}\text { FLOW RATE } \\
\text { MMSCFD }\end{array}$ & YEAR & $\begin{array}{c}\text { FLOW RATE } \\
\text { MMSCFD }\end{array}$ \\
\hline 12 & 3.51 & 2.33 & 526.0 & $2016-2017$ & 300 \\
\hline 13 & 3.75 & 2.48 & 562.5 & $2018-2019$ & 450 \\
\hline 14 & 4.02 & 2.66 & 603.0 & 2020 & 560 \\
\hline 15 & 4.32 & 2.86 & 648.0 & 2025 & 640 \\
\hline 16 & 4.70 & 3.09 & 705.0 & 2030 & 700 \\
\hline
\end{tabular}

Table 8 Report on Initial Design

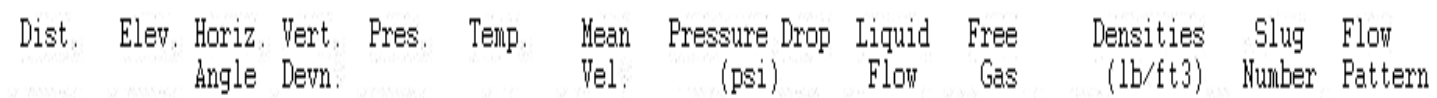

(feet) (feet) (deg) (deg) (psia) (F) (ft/s) Elev. Frictn. (bbl/d) (nnsctd) Iiquid Gas (PI-SS)

RISER Riser_1

Topsides

$\begin{array}{lllllllllllllll}1 & 0.0000 & 0.0000 & -90.0 & 0.000 & 3014.7 & 140.00 & 97022 & 0.0000 & 0.0000 & 68.588 & 10.3615 & 61.491 & 16.650 & \text { ORK SLUG }\end{array}$

$\begin{array}{lllllllllllllll}2 & 0.0000 & -1203 & -90.0 & 0.000 & 3174.0 & 123.63 & .90218 & -159.4 & .03227 & 69.165 & 10.3550 & 61.765 & 17.912 & \text { ORK SLUG }\end{array}$

$\begin{array}{lllllllllllllll}3 & 0.0000 & -2406 & -90.0 & 0.000 & 3342.6 & 112.12 & 85249 & -168.6 & 03081 & 69.386 & 10.3518 & 61.950 & 18.963 & \text { ORK SLUG }\end{array}$

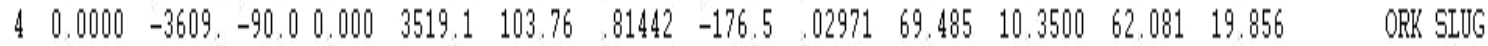

RISER Riser_2

Riser Base

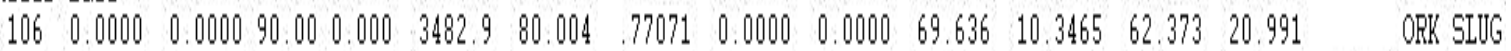

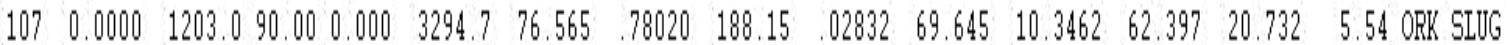

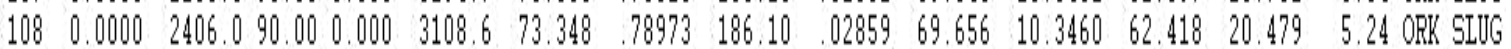

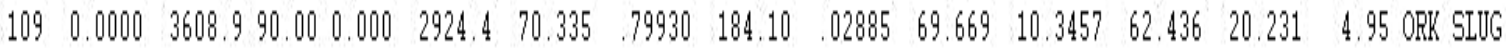


Table 9 Report on the Alternate Design

\begin{tabular}{|c|c|c|c|c|c|c|c|}
\hline RISEF & $\begin{array}{l}\text { Dist. } \\
\text { (feet) } \\
\text { Riser }\end{array}$ & $\begin{array}{l}\text { Elev. } \\
\text { (feet) }\end{array}$ & $\begin{array}{l}\text { Pipe } \\
\text { I.D. } \\
\text { (ins.) }\end{array}$ & $\begin{array}{r}\text { Mean } \\
\text { Length } \\
\text { (feet) }\end{array}$ & $\underset{\substack{\text { Freq } \\
(\min -1)}}{\text { Slug }}$ & $\begin{array}{l}1 \text { in } t \\
\text { Length } \\
\text { (feet) }\end{array}$ & $\begin{array}{l}\text { housand } \\
\text { Freq } \\
\text { (min-1) }\end{array}$ \\
\hline Topsi & des & & & & & & \\
\hline 1 & 0 & 0.0 & 10.000 & - & - & - & \\
\hline & 0 & -600.0 & 10.000 & 0.0 & 0.000 & 0.0 & 0.000000 \\
\hline & 0 & -1200.0 & 10.000 & 0.0 & 0.000 & 0.0 & 0.000000 \\
\hline FLOWI & INE Flo & line_1 & & & & & \\
\hline $\operatorname{ser}$ & Base & & & & & & \\
\hline $\begin{array}{l}4 \\
5\end{array}$ & 1936. & $\begin{array}{r}0.0 \\
52\end{array}$ & $\begin{array}{l}18.000 \\
18.000\end{array}$ & $0 \overline{0}$ & $000 \overline{0}$ & $0 \overline{0}$ & $0.0000 \overline{0}$ \\
\hline 6 & 3872 . & 65.6 & 18.000 & $\begin{array}{l}0.0 \\
0.0\end{array}$ & 0.000 & 0.0 & 0.000000 \\
\hline 7 & 5808 & 117.8 & 18.000 & 0.0 & 0.000 & 0.0 & 0.000000 \\
\hline 8 & 7744 & 131.2 & 18.000 & 0.0 & 0.000 & 0.0 & 0.000000 \\
\hline 9 & 9680 & 183.4 & 18.000 & 0.0 & 0.000 & 0.0 & 0.000000 \\
\hline 10 & 11616. & 196.9 & 18.000 & 0.0 & 0.000 & 0.0 & 0.000000 \\
\hline 11 & 13552 . & 249.0 & 18.000 & 0.0 & 0.000 & 0.0 & 0.000000 \\
\hline 12 & 15488 & 262.5 & 18.000 & 0.0 & 0.000 & 0.0 & 0.000000 \\
\hline 13 & 17424 & 314.6 & 18.000 & 0.0 & 0.000 & 0.0 & 0.000000 \\
\hline 14 & 19360 & 328.1 & 18.000 & 0.0 & 0.000 & 0.0 & 0.000000 \\
\hline $\begin{array}{l}14 \\
15\end{array}$ & 21296 & 380.3 & 18.000 & 0.0 & 0.000 & 0.0 & 0.000000 \\
\hline 16 & 23232 & 3937 & 18.000 & 0.0 & 0.000 & 0.0 & $0 \quad 000000$ \\
\hline 17 & 25168 & 445.9 & 18.000 & 0.0 & 0.000 & 0.0 & 0.000000 \\
\hline 18 & 27104 & 459.3 & 18.000 & 0.0 & 0.000 & 0.0 & 0.000000 \\
\hline 19 & 29040 & 511.5 & 18.000 & 0.0 & 0.000 & 0.0 & 0.000000 \\
\hline 20 & 30976 . & 524.9 & 18000 & 0.0 & 0.000 & 0.0 & 0.000000 \\
\hline 72 & 31646 . & 2231.0 & 18.000 & 0.0 & 0.000 & 0.0 & 0.000000 \\
\hline 73 & 33582 . & 2283.1 & 18.000 & 0.0 & 0.000 & 0.0 & 0.000000 \\
\hline 74 & 35518 . & 2296.6 & 18.000 & 0.0 & 0.000 & 0.0 & 0.000000 \\
\hline 75 & 37454 . & 2348.8 & 18.000 & 0.0 & 0.000 & 0.0 & 0.000000 \\
\hline 76 & 39390 . & 2362.2 & 18.000 & 0.0 & 0.000 & 0.0 & 0.000000 \\
\hline 77 & 41326 . & 2414.4 & 18.000 & 0.0 & 0.000 & 0.0 & 0.000000 \\
\hline 78 & 43262 . & 2427.8 & 18.000 & 0.0 & 0.000 & 0.0 & 0.000000 \\
\hline 79 & 45198. & 2480.0 & 18.000 & 0.0 & 0.000 & 0.0 & 0.000000 \\
\hline 80 : & 47134. & 2493.4 & 18.000 & 0.0 & 0.000 & 0.0 & 0.000000 \\
\hline 81 & 49070 & 25456 & 18000 & 0.0 & 0.000 & 00 & 0.000000 \\
\hline 82 & 51006 . & 2559.1 & 18.000 & 0.0 & 0.000 & 0.0 & 0.000000 \\
\hline $83:$ & 52942. & 2611.2 & 18.000 & 0.0 & 0.000 & 0.0 & 0.000000 \\
\hline 84 & 54878 & 2624.7 & 18.000 & 0.0 & 0.000 & 0.0 & 0.000000 \\
\hline 85 & 56814 . & 2676.8 & 18.000 & 0.0 & 0.000 & 0.0 & 0.000000 \\
\hline 86 & 58750 . & 2690.3 & 18.000 & 0.0 & 0.000 & 0.0 & 0.000000 \\
\hline 87 & 686. & 2742.5 & 18.000 & 0.0 & 0.000 & 0.0 & 0.000000 \\
\hline
\end{tabular}

\section{Conclusions}

The findings of this research are relevant in the transportation of condensate gas from the offshore waters of Ghana mainly the West Cape Three Points, Jubilee Field and TEN Fields to the Atuabo Gas Processing Plant. The following conclusions can be drawn from this study;

(i) A subsea pipeline for transporting condensate from the Jubilee and TEN fields to the Atuabo Gas Processing Plant has been designed. The design employs two subsea temperature control mechanism; insulation of the pipeline and the application of direct electrical heating to the pipelines in order to raise the surrounding temperature above the hydrate formation temperature.

(ii) The maximum designed flow rate is 150 MMSCFD. This is however possible only in the year 2014 and 2015 and will not meet the projected flow rate in the subsequent years where gas production is expected to increase. In order to meet the highest projected flow rate of 700 MMSCFD, a 16 in. ID pipeline of $44 \mathrm{~km}$

\begin{tabular}{|c|c|c|c|c|c|}
\hline $\begin{array}{l}1 \text { in hu } \\
\text { Length } \\
\text { (feet) }\end{array}$ & $\begin{array}{c}\text { Fred } \\
\text { (min-1) }\end{array}$ & $\begin{array}{r}1 \text { in } \\
\text { Length } \\
\text { (feet) }\end{array}$ & $\underset{\substack{\text { Freq } \\
\text { (min-1) }}}{\text { ten }}$ & $\begin{array}{l}\text { Slug } \\
\text { Number } \\
\text { (PI-SS) }\end{array}$ & $\begin{array}{l}\text { Flow } \\
\text { Pattern }\end{array}$ \\
\hline $\begin{array}{l}0 . \overline{0} \\
0.0\end{array}$ & $\begin{array}{c}0.00000 \\
0.00000\end{array}$ & $\begin{array}{l}0 . \overline{0} \\
0.0\end{array}$ & $\begin{array}{r}0.000 \overline{0} \\
0.0000\end{array}$ & & $\begin{array}{l}- \\
\text { ORK BUBBLE } \\
\text { ORK BUBBIE }\end{array}$ \\
\hline $\begin{array}{l}0 . \overline{0} \\
0.0 \\
0.0 \\
0.0 \\
0.0 \\
0.0 \\
0.0 \\
0.0 \\
0.0 \\
0.0 \\
0.0 \\
0.0 \\
0.0 \\
0.0 \\
0.0 \\
0.0\end{array}$ & $\begin{array}{c}- \\
0.00000 \\
0.00000 \\
0.00000 \\
0.00000 \\
0.00000 \\
0.00000 \\
0.00000 \\
0.00000 \\
0.00000 \\
0.00000 \\
0.00000 \\
0.00000 \\
0.00000 \\
0.00000 \\
0.00000 \\
0.00000\end{array}$ & $\begin{array}{l}0 . \overline{0} \\
0.0 \\
0.0 \\
0.0 \\
0.0 \\
0.0 \\
0.0 \\
0.0 \\
0.0 \\
0.0 \\
0.0 \\
0.0 \\
0.0 \\
0.0 \\
0.0 \\
0.0\end{array}$ & $\begin{array}{l}0.0000 \\
0.0000 \\
0.0000 \\
0.0000 \\
0.0000 \\
0.0000 \\
0.0000 \\
0.0000 \\
0.0000 \\
0.0000 \\
0.0000 \\
0.0000 \\
0.0000 \\
0.0000 \\
0.0000 \\
0.0000\end{array}$ & $\begin{array}{r}287.92 \\
136.05 \\
92.02 \\
68.17 \\
54.95 \\
45.42 \\
39.09 \\
33.99 \\
30.28 \\
27.11 \\
24.67 \\
22.51 \\
20.78 \\
19.22 \\
17.94 \\
16.76\end{array}$ & $\begin{array}{l}\text { - } \\
\text { B/B SEGREGAT } \\
\text { B/B SEGREGAT } \\
\text { B/B SEGREGAT } \\
\text { B/B SEGREGAT } \\
\text { B/B SEGREGAT } \\
\text { B/B SEGREGAT } \\
\text { B/B SEGREGAT } \\
\text { B/B SEGREGAT } \\
\text { B/B SEGREGAT } \\
\text { B/B SEGREGAT } \\
\text { B/B SEGREGAT } \\
\text { B/B SEGREGAT } \\
\text { B/B SEGREGAT } \\
\text { B/B SEGREGAT } \\
\text { B/B SEGREGAT } \\
\text { B/B SEGREGAT }\end{array}$ \\
\hline $\begin{array}{l}0.0 \\
0.0 \\
0.0 \\
0.0 \\
0.0 \\
0.0 \\
0.0 \\
0.0 \\
0.0 \\
0.0 \\
0.0 \\
0.0 \\
0.0 \\
0.0 \\
0.0 \\
0.0\end{array}$ & $\begin{array}{l}0.00000 \\
0.00000 \\
0.00000 \\
0.00000 \\
0.00000 \\
0.00000 \\
0.00000 \\
0.00000 \\
0.00000 \\
0.00000 \\
0.00000 \\
0.00000 \\
0.00000 \\
0.00000 \\
0.00000 \\
0.00000\end{array}$ & $\begin{array}{l}0.0 \\
0.0 \\
0.0 \\
0.0 \\
0.0 \\
0.0 \\
0.0 \\
0.0 \\
0.0 \\
0.0 \\
0.0 \\
0.0 \\
0.0 \\
0.0 \\
0.0 \\
0.0\end{array}$ & $\begin{array}{l}0.0000 \\
0.0000 \\
0.0000 \\
0.0000 \\
0.0000 \\
0.0000 \\
0.0000 \\
0.0000 \\
0.0000 \\
0.0000 \\
0.0000 \\
0.0000 \\
0.0000 \\
0.0000 \\
0.0000 \\
0.0000\end{array}$ & $\begin{array}{l}3.51 \\
3.44 \\
3.39 \\
3.33 \\
3.28 \\
3.22 \\
3.18 \\
3.12 \\
3.08 \\
3.03 \\
2.98 \\
2.42 \\
2.29 \\
1.93 \\
1.85 \\
1.60\end{array}$ & $\begin{array}{l}\text { B/B SEGREGAI } \\
\text { B/B SEGREGAT } \\
\text { B/B SEGREGAT } \\
\text { B/B SEGREGAI } \\
\text { B/B SEGREGAT } \\
\text { B/B SEGREGAI } \\
\text { B/B SEGREGAT } \\
\text { B/B SEGREGAT } \\
\text { B/B SEGREGAI } \\
\text { B/B SEGREGAT } \\
\text { B/B SEGREGAI } \\
\text { B/B SEGREGAI } \\
\text { B/B SEGREGAI } \\
\text { B/B SEGREGAT } \\
\text { B/B SEGREGAT } \\
\text { B/B SEGREGAT }\end{array}$ \\
\hline
\end{tabular}

length should be run parallel to the 12 in. ID flowline 1 in order to meet the higher operating flow rate to the processing plant. The addition of 16 in. ID parallel pipeline will increase the design flow rate of 150 MMSCFD by approximately 4.7 times (705 MMSCFD) which meets flow capacity to the plant in the subsequent years.

(iii) An alternate design that eliminates the need for capacity increase of the flowlines for the higher projected flow rates in future was considered. This employs 18 in flowline 1 and 20 in. flow-line 2 with a capacity of 700 MMSCFD, which meets the highest projected flow rate of 700 MMSCFD right from the start.

\section{References}

Akpabio, M. (2013), "Cold Flow in Long-Distance Subsea Pipelines", Unpublished Master Thesis, Norwegian University of Science and Technology, 126pp.

Ameripour, S. (2005), "Prediction of Gas Hydrate Formation Conditions in Production and Surface Facilities", Unpublished MSc Project Report, Texas A\&M University, Texas, 79pp. 
Anand, G and Anirbid, S. (2015), "Need of Flow Assurance for Crude Oil Pipelines: A Review", International Journal of Multidisciplinary Science and Engineering, Vol. 6, No. 2, pp. 43 -49 .

Anon. (2009), "Jubilee Field Environmental Impact Assessment - Chapter 4, Part 1", 42pp. www.tullowoil.com/operations/westafrica/ghana/jubilee-field/environmentalimpact-statement Accessed: February 1, 2017.

Anon. (2013), "Jubilee Project - External Independent Monitoring Report", Vol. 1, 1062pp.www.tullowoil.com/operations/westafrica/ghana/jubilee-field. Accessed: February $1,2017$.

Anon. (2014), “Tweneboa, Enyenra, Ntomme (TEN) Project, Ghana - Final Environmental Impact Statement", Vol. 1, 1062pp. www.tullooil.com/operations/west-africa/ghana/jubileefield Accessed: March 3, 2017.

Ayala, L. F. and Adewumi, M. A. (2003), "LowLiquid Loading Multiphase Flow in Natural Gas Pipelines", Journal of Energy Resource Technology, Vol. 125, pp. 284 -293.

Broni-Bediako, E., Amorin, R., and Bavoh, H. (2017), "Gas Hydrate Formation Phase Boundary Behaviour of Synthetic Natural Gas of the Keta Basin of Ghana", The Open Petroleum Engineering Journal, Vol. 10, pp. 65 - 70.

Convington, K. C. and Collie, J. T. (1997), "Selection of Hydrate Suppression Methods for Gas Streams", Proceedings of the $78^{\text {th }}$ GPA Annual Convention. Nashville, TN: Gas Processors Association, 1999: pp. 46 - 52.

Gabitto, J. F. and Tsouris, C. (2010), "Physical Properties of Gas Hydrate: A Review", Journal of Thermodynamic, Vol. 2010, pp. 1 - 12.

Golczynski, T.S. and Kempton, E. C. (2006), "Understanding Wax Problems Leads to Deepwater Flow Assurance Solutions", World Oil, Vol. 227, pp. 7 - 10.

Guha, I. and Berrones, R. F. (2008), "Earthquake Effect Analysis of Buried Pipelines", $12^{\text {th }}$ International Conference of International Association for Computer Methods and Advances in Geomechanics (IACMAG), Goa, India, 1-6 October, pp. 3957 - 3967.

Karen, S and Ronningsen, H. P. (2003), "Influence of Wax Inhibitors on Wax Appearance Temperature, Pour Point, and Viscosity of Waxy Crude Oils" Energy Fuels, Vol. 17, pp. $321-328$.

McLaughlin, D. (2012), "Jubilee Project Overview", Offshore Technology Conference. Houston, Texas, U.S.A, 30 April - 3May, pp. 1 9.

Marfo, S. A., Opoku Appau, P. and Kpami, L. A. A. (2018), "Subsea Pipeline Design for Natural Gas Transportation: A Case Study of Côte
D'ivoire's Gazelle Field", International Journal of Petroleum and Petrochemical Engineering (IJPPE), Vol. 4, No. 3, pp. 21 - 34.

Mokhatab, S., Poe, W. A. and Speight, G. J. (2006), "Handbook of Natural Gas Transmission and Processing", USA: Gulf Professional Publishing, 672pp.

Moody. L. F., (1944), "Friction Factors for Pipe Flow", Transactions of ASME, Vol. 66, pp. 671 - 678.

Nexans. (2015), “Direct Electrical Heating (DEH) technology keeps subsea flowlines flowing as oil and gas projects go deeper and longer", Offshore Technology Conference. Houston, Texas, May 4-7, U.S.A, pp. 1 - 3.

Nikhar, H. G. (2006), "Flow Assurance and Multiphase Pumping", Unpublished MSc Thesis Report, Texas A\&M University, Texas, 208pp.

Nysveen, A., Kulbotten, H., Lervik, A.H. B. and Hoyer-Hansen, M. (2005), "Direct electrical heating of subsea pipelines - technology development and operating experience", Record of Papers Industry Applications Society 52nd Annual Petroleum and Chemical Industry Conference, Denver, CO, U.S.A, pp. 177 - 187.

Obanijesu, E. O., Pareek, V. and Tade, M. O. (2010), "Hydrate Formation and its Influence on Natural Gas Pipeline Internal Corrosion Rate", SPE Oil and Gas India Conference and Exhibition, Mumbai, India, 20-22 January, pp. 1 $-11$.

Okologume, W and Appah, D. (2015), “Analysing Thermal Insulation for Effective Hydrate Prevention in Conceptual Subsea Pipeline Design", International Journal of Current Engineering and Technology, Vol. 5, No. 4, pp. 2492 - 2499.

Ripmeester, J. A., Tse, J. S, Ratcliffe, C. I., and Powell, B. M. (1987): "A New Clathrate Hydrate Structure", Nature, Vol. 325, pp. 135 136.

Singh, R. R, and Nain, P. K. S (2012), "Optimization of Natural Gas Pipeline Design and Its Total Cost Using GA", International Journal of Scientific and Research Publications, Vol. 2, Issue 8, pp. 1 - 10.

Sum, A. K. (2013), "Prevention, Management, and Remediation Approaches for Gas Hydrates in the Flow Assurance of Oil/Gas Flowlines", Offshore Technology Conference, held in Rio de Janeeiro, Brazil, 29-31 October, pp. $1-6$.

Theyab, M. A. and Diaz, P. (2016), Experimental Study of Wax Deposition in Pipeline- Effect of Inhibitor and Spiral Flow", International Journal of Smart Grid and Clean Energy, Vol. 5, No. 3, pp. 174 - 181.

Weinbel, R. C and Araujo, R (2012) "Jubilee Field FPSO - A Fast track Delivery Success", Offshore Technology Conference, held in 
Houston, Texas, USA, 30 April - 3 May, pp. 1 -10 .

Weymouth, T.R., (1912), "Problems in Natural Gas Engineering", Transactions of the American Society of Mechanical Engineers, No. 1349, Vol. 34, pp. 185 - 231.

\section{Authors}

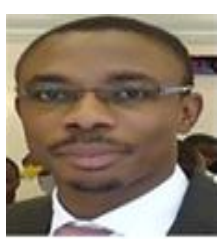

Solomon Adjei Marfo is a Lecturer at the Petroleum Engineering Department of University of Mines and Technology, Tarkwa, Ghana. He holds $\mathrm{PhD}$ in Petroleum Engineering from the University of Port Harcourt, Nigeria, MEng Degree in Mining (Petroleum Engineering) from the University of Belgrade, Serbia and BSc in Chemical Engineering from the Kwame Nkrumah University of Science and Technology, KNUST, Kumasi, Ghana. He is a member of the Society of Petroleum Engineers (SPE), a Registered Environmental Specialist (RES) with the National Registry of Environmental Professionals (NREP) of USA. His research interests include sand and water control in oilfields using chemicals application of Artificial Neural Network (ANN) in the Petroleum Industry, agro-waste and local materials evaluation for oilfields application.

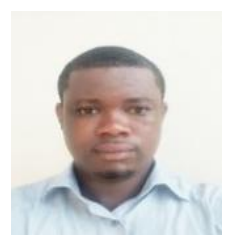

Prince Opoku Appau is an MSc degree student at China University of PetroleumBeijing, majoring in Petroleum and Natural Gas Engineering. He holds BSc degree in Petroleum Engineering from the University of Mines and Technology, Tarkwa, Ghana. He is also a member of Society of Petroleum Engineers (SPE). His research interests include rock petrophysics, reservoir engineering, EOR and natural gas engineering.

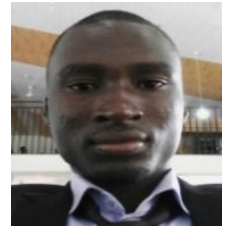

Joseph Acquah is a graduate from the University of Mines and Technology, Tarkwa. He holds BSc in Petroleum Engineering from the University of Mines and Technology, Tarkwa. He is a member of Ghana Institution of Engineers (GHIE), Society of Petroleum Engineers (SPE). His research interests include oil and gas pipeline design and modeling; gamma column scanning of petroleum facilities; aerosol optical depth (AOD) distribution and their impacts; ultrasonic thickness testing of gas storage facilities.

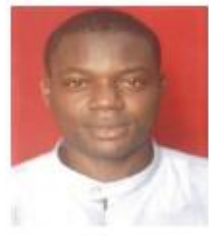

Eric Mensah Amarfio is a lecturer and a $\mathrm{PhD}$ candidate at the University of Mines and Technology, Tarkwa, Ghana. He obtained his MSc in Petroleum Engineering from African University of Science and Technology, Abuja, Nigeria and his BSc in Chemical Engineering from the Kwame Nkrumah University of Science and Technology, Kumasi, Ghana. He is a member of the Society of Petroleum Engineers International, USA, and the Editorial board of the International Journal of Petroleum and Petrochemical Engineering, India. His research areas of interest are; Nano drilling fluids technology, Reservoir and production optimisation, Enhanced oil recovery, and Petroleum Economics. 